\title{
Household Switching Behavior at Depository Institutions: Evidence from Survey Data
}

\author{
Elizabeth K. Kiser*
}

August 14, 2002

\begin{abstract}
Understanding household deposit relationships is central to the analysis of competition and the application of merger policy in banking. This article presents descriptive findings from new survey data on households' decisions to change or remain with their providers of checking or savings accounts. The data show that the distribution of household tenure is wide, and that about a third of households have never changed depository institutions. The primary reason reported for changing banks is a household relocation; other reasons are customer service and price factors. Customer service and location are the most frequently cited reasons for remaining with a bank. The importance of location and mobility supports previous survey evidence that the local area is the appropriate market for competitive analysis in banking. The findings presented here are consistent with earlier studies showing that population migration increases competitive pressure on firms and therefore should mitigate the anticompetitive effects of bank mergers.
\end{abstract}

*Economist, Federal Reserve Board, $20^{\text {th }}$ and C St., NW, Washington, DC 20551, (202) 452-2584, elizabeth.kiser@frb.gov. The views expressed in this paper are those of the author and not necessarily those of the Federal Reserve Board. I would like to thank Bob Adams, Dean Amel, Marianne Bitler, Myron Kwast, Robin Prager, Steve Rhoades, Paul Smith and members of the Financial Structure Section in the Division of Research and Statistics at the Federal Reserve Board for helpful comments. 


\section{Introduction}

Because customer substitution across products and services influences market competition, an understanding of household relationships to deposit account providers is important in guiding bank merger policy. This study looks to new survey data to elicit information on household behavior at depository institutions. While other surveys have investigated deposit relationship durations, this survey is unique in that it asks deposit account holders explicitly about specific reasons for changing banks or remaining with a bank. The information reveals the relationship dynamics between households and their depository institutions and explores the importance of location, mobility, bank characteristics and prices in deposit markets.

The results show that the typical household tenure at depository institutions is long (10 years), and that the most frequently cited motivation for changing banks is a household relocation. Among households that have changed banks for other reasons, customer service and price factors are the most frequently cited motivations for changing banks. Customer service and location are the most frequently reported reasons for remaining with a bank. The findings that half of households that have changed banks cite relocation as the main reason for the most recent change, and that three fourths of households with bank accounts cite location as a primary reason for remaining with a bank, support the ongoing use of the local banking market as the relevant market for analyzing bank mergers. Because household bank switches are most likely to occur because of a household relocation, customers are more likely to shop on the basis of prices and quality when they move. This finding corroborates earlier studies that find greater competitive pressures on banks in markets with high population turnover.

During the bank merger review process at the relevant regulatory authorities, considerable attention is given to local market conditions that may mitigate the potentially anticompetitive effects of mergers. For example, market size, market growth, and commuting patterns that affect the range of depository institutions available to customers have been cited as mitigating factors in bank merger cases. Economic research at the bank and market level has shown some of these variables to be statistical predictors of firm entry. For example, Amel and Liang (1997) show that de novo bank entry is more likely to occur in large and growing markets. However, little research has been 
conducted at the micro level to explain the mechanisms by which these factors influence the probability of entry. In addition, the supply of deposits has been estimated to be relatively price inelastic, suggesting that households may not be very responsive to price differences across depository institutions. ${ }^{1}$ This, in turn, would imply that entry may be difficult, if low cross-price elasticities mean that banks cannot easily attract new customers away from existing competitors. Again, little research on households or businesses has indicated what might explain this finding.

Deposit supply inelasticity could result from different underlying causes. Deposit relationships typically involve a stable relationship with a firm that provides a flow of services over time. Anecdotal evidence suggests that for some banking customers, the act of establishing or closing a deposit account may involve spending valuable time or tying up needed funds. Economic research suggests that such switching costs may reduce competition by increasing the change in prices or quality that would be necessary to induce a customer to change banks. This effect could in turn reduce the probability of firm entry even in the presence of high prices, as it would be difficult for new firms to attract customers away from other depository institutions. Another explanation for supply inelasticity is the multi-dimensional nature of deposit accounts. If customers have preferences for such characteristics as location or office hours, then the bundle of banking services is differentiated, relaxing the degree of direct price competition across firms.

The findings presented below address both switching costs and product differentiation, providing a richer explanation for the patterns exhibited in previous aggregate-level research. In addition, the correlations across responses indicate how preferences and behavior vary in the population. Finally, the results show differences in switching behavior across age groups that help predict future behavior.

\footnotetext{
${ }^{1}$ See Amel and Hannan (1999).

2 See Zephirin (1994), Sharpe (1997), and Kim, Kliger and Vale (2001).

${ }^{3}$ For a survey on the effects of product differentiation on pricing, see Eaton and Lipsey (1996).
} 


\section{Data and Descriptive Findings}

The data set analyzed in this study comes from the Michigan Surveys of Consumers, an ongoing monthly telephone survey of 500 U.S. households administered by the Michigan Survey Research Center as a rotating panel. ${ }^{-1}$ The Michigan Survey is best known for a core set of questions on households' attitudes and expectations about their own financial matters and about the economy at large. Each survey also contains a full set of household demographic variables. A special module on household banking behavior was sponsored by the Federal Reserve Board to elicit information on household switching among depository institutions. This group of questions was administered for three consecutive months in June, July and August, 1999, resulting in a sample of 1500 distinct households whose responses are analyzed in this article. A sampling weight is constructed for each household to scale the data to a nationally representative sample; these weights have been applied to all calculations.

Respondents in the survey were first asked whether any member of the household has a checking or savings account with a depository institution. ${ }^{6}$ Households with at least one checking or savings account were asked to designate the depository institution where they hold their most frequently used checking account (or savings account, if they have no checking account) as their "main bank." Households with a checking or savings account were then asked additional questions on the details of their relationship with their bank, such as the tenure of the deposit relationship and the reasons for changing or staying with the institution. The questions in this survey focus on deposit accounts rather than other products (such as loans) because checking accounts are by far the most widely held financial product of households. Also, while empirical research has been conducted on the importance of lending relationships, little work has explored how and why households switch providers of deposit accounts.

\footnotetext{
${ }^{4}$ Each month, an independent random cross-section is drawn using random-digit telephone dialing. This set of households is re-interviewed six months later. The interviews are conducted so that in any given month, approximately 60 percent of households in the sample are new respondents, and 40 percent are households being interviewed for a second time.

${ }^{5}$ Due to the application of sampling weights to generate the descriptive statistics, the number of observations reported as responses to specific questions do not correspond to the reported percent frequencies in the descriptive analysis.

${ }^{6}$ In this paper, a "household's response" refers to the respondent's reply on behalf of the household.

${ }^{7}$ See Petersen and Rajan (1994) and Berger and Udell (1995) as examples from the large body of literature on small-business lending relationships.
} 
The possibility that households substitute nondepository accounts for traditional bank accounts is an important possibility. Specifically, a household could use a money market mutual fund as a substitute for a traditional checking account. Focusing only on household switching behavior at depository institutions and overlooking alternative types of transaction accounts could lead us to underrepresent the degree of competition faced by depository institutions. To check for this type of substitution, the number of households in the sample were tallied that (1) reported having no checking or savings account with a depository institution and (2) held a money market mutual fund. Three of the 1500 households in the data set satisfied these criteria; these households constitute about 2 percent of households that have no checking or savings account at a depository institution. This number appears too small to investigate further. These findings suggest that it is unlikely that many households use money market mutual funds as transaction accounts to the exclusion of traditional accounts at depository institutions.

\section{Households with a Checking or Savings Account}

Table 1 summarizes responses to the questions on checking and savings account ownership. Eighty-nine percent of households reported having either a checking or a savings account with a depository institution. Those households reporting no such account tended to have lower income and education levels relative to other households, and were more likely to report a minority ethnicity. ${ }^{\text {G }}$ These findings are consistent with results from the 1998 Survey of Consumer Finances. 0

\footnotetext{
${ }^{8}$ For a comparison of the characteristics of traditional transaction accounts and money market mutual funds, see Pilloff (1999). In contrast to checking accounts, money market mutual funds typically have minimum check amounts and higher minimum balance requirements. Furthermore, cash is generally not accessible from a money market mutual fund through ATMs.

${ }^{9}$ About 69 percent of households with no bank account reported total income less than $\$ 20,000$, as compared to 20 percent overall, and only 9 percent of households with no bank account had a college degree, as compared with 39 percent overall. About 54 percent of respondents with no bank account were of minority ethnicity, as compared with 20 percent overall.

10 The 1998 Survey of Consumer Finances shows 89.5 percent of households to hold a transaction (checking, savings or money market) account of some type. For a full description of findings in this survey, see Kennickell, Starr-McCluer and Surette (2000).
} 


\section{Tenure at Depository Institutions}

Each household with a depository institution was asked the number of years since the household first became a customer at its main bank. Any household whose bank had merged or been acquired was asked to report tenure from the beginning of the initial relationship. Households' reported tenure is long - the median period of time at the main bank is 10 years. Figure 1 shows the frequency distribution of reported years at the current main bank. While a substantial proportion of households have relatively short tenure (37 percent gave a tenure of 5 years or fewer), the distribution shows many households with much longer tenure. Eighteen percent of households report tenure greater than 20 years, and 9 percent report more than 30 years. The maximum reported tenure among households in the sample is 63 years.

It is clear from this distribution that for many households, no switch has been undertaken recently. However, the underlying reasons for these lengthy relationships with depository institutions are unclear - the patterns could be driven by customer preference for institutions that provide favorable products, service or prices, inertia caused by barriers to switching, or both. The following discussion of reasons for changing or staying with the main bank provides some insight into the factors driving household tenure.

\section{Households at their First Bank Ever}

After establishing a household's tenure at its main bank, the survey asked whether the current bank is the household's (or the respondent's) first ever. Thirty-two percent of households with bank accounts reported that their current main bank is the first depository institution where they have ever had an account. Because the tendency of households to change or remain with a bank impacts competition, it is useful to investigate whether households that have never switched differ systematically from households that have changed banks at least once. For example, if households at their first bank ever have short tenure, they may be at least as likely as other households to change banks in response to changes in prices or service. However, if these households have been with their banks for longer periods of time, they may have revealed themselves to be less likely than other households to change banks for any reason. 
Figure 2 shows the tenure distribution conditional on whether the household is at its first bank ever. Most households that have changed banks lie in the lower end of the tenure distribution - 43 percent of these households have been at their bank for 5 or fewer years. In contrast, only 23 percent of households at their first bank ever have tenure of 5 or fewer years. Households at their first bank ever have more evenly distributed tenure, with a substantial proportion (about 20 percent of households at their first bank ever) with tenure of 30 or more years. We can thereby infer that households at their first bank do not consist exclusively of households that have obtained their bank accounts relatively recently.

To investigate this relationship further, we turn to table 2, which shows the percentage of households at their first bank ever, conditional on the age of the respondent. Remarkably, households in the oldest age category are as likely as households in the youngest age category to be at their first bank ever. Households in the middle two age categories are less likely than households in the youngest or oldest categories never to have changed banks. These conditional probabilities suggest a cohort effect rather than an age effect in switching behavior. Specifically, households in the middle age categories can never become as likely as older households never to have switched banks. It is not clear from this analysis what underlies the greater likelihood for the older cohort never to have changed banks. 11 This phenomenon suggests that the propensity to switch may be increasing across generations; such a change would mean that competitive pressures on banks should strengthen over time.

\section{Primary Reasons for Changing Banks}

The 964 households that had changed banks at least once were asked the primary reason for their most recent (active) bank change. ${ }^{12}$ This question was posed with three mutually exclusive categorical responses: because of a move from one town to another,

\footnotetext{
${ }^{11}$ This cohort effect is confirmed in a multivariate analysis of households at their first bank in Kiser (2002).

${ }^{12}$ The households not at their first bank ever are assumed to have actively changed banks - that is, closed their deposit account(s) and opened another at a different institution - at least once. (It is possible that some households may have instead opened their current account without discontinuing a relationship at a previous institution.) All questions that referenced a bank change explicitly were phrased to imply that the household had actively moved accounts from one institution to another.
} 
because of a move or job change within the same town, or some other reason. Table 3 summarizes the responses to this question. Thirty-six percent of households that had changed banks reported the most recent change was due to a move from one town to another, and fifteen percent reported the change was due to a local move or a local job change. The remainder responded that some other reason had led them to change banks. Thus, about half the households that had changed banks at some time reported that their most recent bank change was due to a relocation of some type. ${ }^{13}$ This finding strongly suggests that a substantial number of households find a local presence important for a deposit relationship.

\section{Other Reasons for Changing Banks}

The 469 households that reported "some other reason" (i.e., not a household relocation) as the primary motivation for the most recent bank change were asked more specific information about the change. Five non-mutually exclusive factors were offered as possible important reasons for the bank change, presented as yes/no questions.

The affirmative response rates for questions on specific reasons for the most recent bank change are reported in table 4. The leftmost numeric column displays the percent frequencies among households that were asked this set of questions. The reason receiving the most affirmative responses (56 percent) was better customer service. Prices (interest rates, maintenance fees, or minimum balance requirements), location of the bank's ATMs or offices, and access to electronic services (such as direct deposit, electronic bill payment, or PC banking) had affirmative response rates of 49, 37 and 27 percent, respectively. Twenty-three percent reported that they changed banks most recently because their previous bank merged with another firm. Eleven percent of the households that were asked these questions did not respond affirmatively to any of the listed reasons. The two right columns of table 4 show the affirmative response rates to these questions expressed as a percentage of all households that have ever changed banks and as a percentage of all households with a bank account.

\footnotetext{
${ }^{13}$ This means that about half of households' most recent bank changes were caused by a move, but does not imply what proportion of moves induces a bank change. Because the survey does not ask whether the household has moved recently, it is not possible to calculate the proportion of households that changed banks among households that moved recently.
} 
Note that households were asked the specific reasons for changing banks only if they listed "some other reason" rather than a move or a job change as their primary reason for their most recent bank change. Thus, although location was cited by only 37 percent of households that initiated for reasons other than a move, location (or relocation) is arguably by far the most frequently cited reason for a bank change, since it is implicit in a move or job change. The high affirmative response rate for customer service also underscores the importance of non-price characteristics in the decision to change banks.

Households' reported consideration of price factors reveals some information about customer response to prices relative to other bank characteristics. Given that a household has initiated a bank change for some reason other than a move, prices appear to be an important factor in changing banks. However, the households reporting prices as a primary reason for a change represent only 22 percent of households that report having ever changed banks, and only 15 percent of all households with bank accounts. Of course, it is likely that households that had initiated their most recent change because of a relocation or households at their first bank ever also chose their bank at least partly in response to price factors. Nonetheless, these other households do not appear to have initiated a recent bank change due to prices.

The affirmative response rate to a merger as a reason for the most recent bank change is equal to about 7 percent of all households with bank accounts. Although the preceding questions on tenure imply that a merger or name change does not constitute the household's having changed banks, it is possible that some respondents interpreted a bank name change as a change of bank. To explore this possibility, the frequencies of responses to the merger question were tabulated conditional on responses to the other specific reasons for changing banks. If the respondent interpreted a name change as a bank change, then the merger should constitute the household's only specific reason for having changed banks, since all other reasons imply that a difference between the characteristics of distinct banks induced a bank change. Of the households responding "yes" to the merger question, 23 percent responded affirmatively to no other reason for changing banks. Thus, if this proportion represents the maximum possible affirmative response due to an incorrect interpretation of the question, then the remaining 77 percent of these households have actively undertaken a bank change in response to a merger. 
This implies that a minimum of 5.6 percent of households with bank accounts have actively changed banks in response to a merger (as opposed to the 7.1 percent that responded affirmatively to the merger question, shown in table 4).

Little empirical research has documented the probability that a customer of a target or acquiring firm in a merger will change banks in response to the merger. Indeed, because the survey instrument does not ask households whether or how long ago they may have experienced a bank merger, we cannot conclude what proportion of households in this sample that have actually experienced a bank merger also switched banks in response. Some empirical evidence is available on the experience of banking offices that are divested as part of a regulatory agreement to reduce the anticompetitive impact of bank mergers. Burke (1998) documents that 72 percent of banking offices divested over the period 1985-1992 lost deposit market share in the first year after being purchased. He shows that most of these deposits appeared to flow to depository institutions other than the acquiring firm in the merger; that is, account holders did not appear to transfer their deposits to a non-divested office of their original bank. While the magnitude of this short-term deposit "runoff" at divested branches is not reported, the author does note that most divested branches do not lose substantial market share over the several years following a merger, and that nearly all such branches remain economically viable. The study does not examine the experience of non-divested branches of merger targets. It is unobservable from the survey data presented here whether households reporting a bank change in response to a merger were customers of divested or non-divested branches.

While the format of asking multiple yes/no questions implies that the reasons for changing banks cannot be ranked in importance, it has the advantage that the respondent may list multiple reasons for changing. The correlations for the reasons for changing banks are presented in table 5. Most of the specific reasons for changing banks are positively correlated; an exception is the negative correlation between prices and a merger as reasons for changing banks. This relationship suggests that merger-related switches were initiated because of dissatisfaction with non-price factors associated with the merger. Indeed, the merger response is positively correlated with customer service and electronic services as reasons for changing. Thus, while deposit rates have been documented to move downward (i.e., become less competitive) in the wake of bank 
mergers (see Prager and Hannan [1998]), customers in this sample do not appear likely to actually change banks in response to price changes occurring after a merger.

\section{Reasons for Staying at the Current Bank}

All 1341 households that had been with their current bank for at least one year were presented with a set of yes/no questions about why they had stayed with their current bank. (Note that some, but not all, households were asked both the "staying" and the "switching" questions.) These questions were structured to resemble the questions on changing banks. Table 6 summarizes the responses to this set of questions. Customer service again received the greatest proportion of affirmative responses (75 percent). Location, prices and electronic banking services received 74, 59 and 58 percent affirmatives, respectively. Thirty-four percent reported that they have stayed with their bank so far "because it would be too much trouble" to close their account and open a new one elsewhere. Three percent of households did not respond affirmatively to any of these questions.

The fraction responding affirmatively to each staying question was considerably larger than the fraction responding affirmatively to the comparable switching question. 14 Customer service received the highest rate of affirmative responses relative to other reasons for both switching and staying. Location, however, appears relatively more important for staying than for switching (conditional on the household's having changed for some reason other than a move or job change). Specifically, location ranks on the same scale as customer service in the staying questions, surpassing the price variable in its affirmative response rate. This is perhaps unsurprising, given the nature of the choice of financial institution. The locations of bank offices and branches change seldom relative to an individual's home or workplace. If a household is geographically stable, we expect location to be an unlikely reason to change institutions, but to be a prominent reason for retaining an institution.

\footnotetext{
${ }^{14}$ Comparing tables 3 and 5 , it is not immediately clear why the affirmative response rate is so much greater for the questions on staying than for the questions on switching. The rate of affirmative response may be higher because the reasons offered better address the decision to stay with the current bank than the decision to switch from a previous bank. However, in contrast to switching banks, which is a deliberate action, staying with the current bank is generally passive. It is possible that respondents may be less clear
} 
The affirmative rate for electronic banking services is higher relative to other reasons for staying than for switching. This finding is consistent with switching costs or loyalty resulting from a complex arrangement of direct deposit and automatic debit relationships, or a reliance on PC or Internet banking. Also, it is possible that some households interpreted the question on electronic banking services to include access to ATM networks, in which case households could again be expressing a preference for location. In fact, the positive correlation between location and electronic services as reasons for staying (see table 7) is consistent with households having interpreted electronic banking services to include access to ATMs.

The question whether it would be "too much trouble to close your account and open a new one elsewhere" allows us to begin to distinguish switching costs from a customer preference for the bank's prices and characteristics. If bank customers perceive that their current bank is not their optimal choice, yet do not switch because of the inconvenience, then switching costs are likely endowing institutions with at least some degree of market power over their own customers. The fact that 34 percent of households with a checking or savings account report they have not switched banks at least in part because it would be too inconvenient suggests that switching costs are important to these households' decisions.

One caveat is that a household's response to this question is by no means a perfect indicator of switching costs. First, not all costs of changing banks are captured by this question, which refers to convenience rather than price. For example, pecuniary costs such as the price of new checks are switching costs, yet are not reflected in the question. Furthermore, the question is not phrased to elicit information on search costs, which can be considerable, particularly given the multi-dimensional nature of a deposit account. Finally, the question is phrased so that respondents do not necessarily distinguish the cost from the benefits of switching. Because the question asks whether it would be "too much trouble" to switch, it could be that some customers perceive some inconvenience to switching (a switching cost) but respond negatively to this question because the inconvenience has not prevented them from switching. In this respect, the 34 percent that

about their specific reasons for staying, and may be more suggestible when presented with a set of yes/no reasons. 
answered affirmatively may represent a lower bound on the proportion of households that perceive some type of switching costs.

As is shown in table 7 , most of the correlations among reported reasons for staying are positive. However, prices, customer service and electronic services are negatively correlated with "too much trouble." The negative relationship between prices and "too much trouble" is consistent with the theoretical prediction that switching costs increase the price increase that would be necessary to induce a customer to switch. ${ }^{15}$ The negative relationship between "too much trouble" and the other two variables (customer service and electronic services) suggests that households reporting it to be too inconvenient to switch may be less satisfied than other households with the characteristics or services of their bank. The next survey question deals with customer satisfaction directly.

\section{Customer Satisfaction}

Respondents were presented with a categorical question on the household's level of satisfaction with their main bank. The frequency distribution for this variable is presented in the first column of table 8. A large proportion of households - 53 percent reported they are "very satisfied" with their main bank. Thirty-four percent reported being "moderately satisfied," and 7 percent reported being "neither satisfied nor dissatisfied." Five percent of households reported being "moderately dissatisfied," and only 2 percent reported being "very dissatisfied" with their main bank. These numbers suggest that relatively few households appear very unhappy with their financial institutions. However, the reported level of satisfaction reveals no information about how the household would compare the characteristics of its bank with those of alternative institutions (which might result in greater satisfaction). Furthermore, respondents certainly apply no uniform method of translating their individual preferences into corresponding satisfaction levels that would be comparable across households.

Due to the subjective nature of reported customer satisfaction, it is difficult to interpret the response to this question independently. However, we can investigate

\footnotetext{
${ }^{15}$ For a survey of the theoretical literature of the effects of switching costs on pricing, see Klemperer (1995).
} 
whether the distribution of satisfaction levels varies with the responses to other questions. The right two columns of table 8 show the frequency distributions of customer satisfaction conditional on whether the household answered "yes" or "no" to whether it was too inconvenient to switch. The frequency distribution of satisfaction levels for households responding affirmatively to "too much trouble" indicates lower satisfaction than for households responding negatively. Considering the converse proportions (not shown in the table), only 29 percent of very or moderately satisfied households reported it was too inconvenient to switch, compared with 63 percent of households that were neutral or moderately or very dissatisfied. Finally, one could argue that households that report being less than "very" satisfied and report it to be "too much trouble" to switch are those that are most likely to have perceived switching costs that have prevented them from obtaining their optimal choice. ${ }^{16}$ This set of households makes up about 23 percent of those that have been at their main bank for at least one year.

\section{Implications for Competition Among Providers of Deposit Accounts}

The findings presented above have implications for competition among providers of deposit accounts. First, because households change banks relatively infrequently, and because about a third of households report that it would be too inconvenient to switch banks, we can infer that some inertia exists in household banking relationships. If banking customers tend not to switch except in response to substantial price or service differentials, then large-scale de novo entry into banking markets should be difficult. However, entry by acquisition should be successful. These implications are, in fact, consistent with observed entry patterns - de novo entry typically occurs on a small scale, while entry by acquisition often results in dramatic changes in local market shares and concentration. ${ }^{17}$ Note that if the cohort effect apparent in the data means that customers' propensity to switch is increasing over time, this trend could increase competitive pressures on depository institutions.

\footnotetext{
${ }^{16}$ This premise assumes that alternative banks are available to the customer that could result in higher levels of customer satisfaction.

${ }^{17}$ See, for example, Amel and Liang (1997), who analyze de novo entry in local banking markets. Rhoades (1999) provides a summary of recent merger movements.
} 
In addition, when households do change institutions, the switch is most frequently due to a household relocation. If a move forces a customer to change banks, then the move effectively overwhelms the importance of transaction costs in changing banks. This reasoning suggests that turnover in the population may be an important factor in maintaining competitive pressure on depository institutions - overall response to prices should be stronger in areas where many customers are moving into the market than in those with little population turnover. This consequence is consistent with market-level empirical studies, such as Sharpe (1997) and Calem and Carlino (1991), that show deposit and loan interest rates to be more favorable to consumers in markets with high rates of population in-migration.

Retail banking for households and small businesses has traditionally been an industry for which geographic proximity between a customer and the depository institution is extremely important. Recent household and small business surveys show that a very large proportion of households and small businesses are located a very short distance from their main banks. 18 Along with results presented here on moving as a reason for changing banks and location as a reason for staying with a bank, these previous findings provide strong evidence that a majority of customers continue to choose among locally available banks.

This conclusion does not contradict the increasing geographic scope of large banking organizations in the wake of the removal of restrictions on interstate banking and branching. Indeed, empirical evidence suggests that geographic scope can improve banks' risk management and access to capital markets through asset diversification, and that increasing institution size (over moderate size ranges) can allow banks to achieve cost reductions through scale economies. ${ }^{19}$ Rather, the ongoing local nature of banking on the customer side simply confirms that the relevant market for assessing competition in retail banking services continues to be the local area. 0

\footnotetext{
18 For example, Kwast, Starr-McCluer and Wolken (1997) report that half of households and small businesses hold their primary checking account at a depository institution within 3 miles. Using more recent data, Amel and Starr-McCluer (2002) confirm these findings for households.

19 See Hughes and Mester (1998) for evidence on economies of scale in risk management and risk signaling. For an overview of findings on consolidation and efficiency, see Hanweck and Shull (1999).

${ }^{20}$ For a discussion of the distinctions between the geographic scope of banks versus the geographic scope of banking markets, see Heitfield (1999).
} 
The survey reveals information about households' response to prices as opposed to non-price factors. Only 15 percent of all households with checking or savings accounts report that they have changed banks most recently in order to receive more favorable prices; other households do not appear to have initiated a recent bank change due to prices. These findings suggest a relatively weak response to prices. Furthermore, ranking below relocation, customer service was cited most frequently as a reason for changing banks. These findings underscore that deposit relationships are multidimensional, and that this differentiation likely strongly decreases customer responsiveness to prices.

Still, about half of households that had initiated a bank change for some reason other than a move considered prices a primary reason for the change. It is not clear from the survey how households that were not asked the specific reasons for changing actually chose their banks originally. We can speculate that prices would be among the reasons considered in choosing a new institution. This distinction has strong implications for the competitive environment. If households are unlikely to initiate a bank change on the basis of prices, then banks may perceive weak competitive pressure to maintain favorable

prices. If, however, many households are moving into a market, and are comparing prices in order to choose among firms, then depository institutions should face greater competitive pressure.

Finally, while population turnover mitigates the effects of switching costs on prices and firm entry, consolidation continues to create larger banks whose physical presence may span many local banking markets. This, in turn, may mean that increasing numbers of bank customers can move across markets without needing to change banks. Thus, the pro-competitive effect of population turnover may decrease if a household relocation no longer necessitates a change of banks.

\section{Conclusion}

The survey data analyzed in this study show that location continues to be an important factor in households' choice of depository institution, and that relocation is the most frequently cited reason for a change of bank. While price factors are important among the third of households that have initiated a change for reasons other than a 
relocation, relatively few households overall appear to have initiated a bank change mainly because of price factors. Households show substantial heterogeneity in both the likelihood of switching and in the responsiveness to prices or a preference for specific bank characteristics. The differentiation of banks and banking products as well as the heterogeneity in customer preferences appears to be central to customer behavior.

Mergers appear to have induced the most recent change of banks for between 5 and 7 percent of all households with bank accounts. Correlation coefficients between a merger and other reasons cited for changing banks indicate that households are more likely to switch after a merger because of non-price factors, such as customer service, rather than in response to any price changes that may have occurred.

The tendency of households to remain with a bank for many years, along with the third of households that cite the inconvenience of switching as a reason for remaining with their bank, suggests that substantial changes in prices or services may be necessary to induce many households to change institutions. Two phenomena may counteract this inertia in deposit relationships.

First, although tenure is relatively long (with a median of 10 years), the oldest households are as likely as the youngest households never to have changed banks, and households in the middle age groups are less likely than either of these groups to be at their first bank ever. This suggests that the tendency to change banks may be increasing over time, which could consequently increase competition in the future.

Second, because a move is the most frequently cited reason for changing banks, population migration across local markets should counteract household inertia and thereby help maintain pressure on depository institutions to offer attractive prices and services. These findings are consistent with previous research on bank pricing and entry. One caveat, however, is that consolidation in banking continues to generate larger banks whose physical presence spans many local banking markets. This, in turn, may mean that increasing numbers of bank customers can move across markets without needing to change banks, decreasing the likelihood of switching and weakening the competitive impact of population turnover. 
Table 1: Checking or Savings Account Ownership

\begin{tabular}{c|c}
\hline Account ownership status & $\begin{array}{c}\text { Percent of } \\
\text { households with } \\
\text { this account }\end{array}$ \\
\hline Has either a checking or savings account at a depository institution & 89.4 \\
\hline Has a checking account & 85.9 \\
\hline Has a savings (but no checking) account & 3.6 \\
\hline Number of observations & 1496 \\
\hline
\end{tabular}

All 1378 households with a checking or savings account were asked about tenure. Thirty-seven households did not respond to this question. Frequencies are calculated using sampling weights. 
Table 2: Percent of households at 'first bank ever' by age category

\begin{tabular}{|c|c|c|c|c|c|}
\hline & \multirow{2}{*}{$\begin{array}{c}\text { Among all } \\
\text { households* }\end{array}$} & \multicolumn{4}{|c|}{ By age of respondent } \\
\cline { 4 - 6 } & & Age <35 & Age 35-49 & Age 50-64 & Age 65+ \\
\hline $\begin{array}{c}\text { Percent at } \\
\text { first bank } \\
\text { ever }\end{array}$ & 32.3 & 40.2 & 23.9 & 26.9 & 40.7 \\
\hline $\begin{array}{c}\text { Percent not } \\
\text { at first bank } \\
\text { ever }\end{array}$ & 67.7 & 59.8 & 76.1 & 73.1 & 59.3 \\
\hline $\begin{array}{c}\text { Number of } \\
\text { observations }\end{array}$ & 1359 & 344 & 488 & 310 & 208 \\
\hline
\end{tabular}

*Percentages are calculated among households with a checking or savings account. Sampling weights are applied to calculate percentages. The number of observations across age categories does not sum to the number among all households because of the nonresponse of 9 households to the age question. 
Table 3: Primary Reason for Most Recent Bank Change

\begin{tabular}{l|c}
\hline \multicolumn{1}{c|}{ Primary reason for most recent bank change } & $\begin{array}{c}\text { Percent } \\
\text { Frequency }\end{array}$ \\
\hline Moved towns & 36.4 \\
\hline Moved or changed jobs within town & 14.9 \\
\hline Some other reason & 48.8 \\
\hline Number of observations & 961 \\
\hline
\end{tabular}

Only the 964 households that were not at their first bank ever were asked the primary reason for the most recent bank change. These categorical responses are mutually exclusive. Three households did not respond to the question. Frequencies are calculated using sampling weights. 
Table 4: Reasons for most recent bank change, if not for a move or job change

\begin{tabular}{|c|c|c|c|}
\hline \multirow{2}{*}{$\begin{array}{l}\text { Specific reasons for most recent } \\
\text { bank change (other than a move or } \\
\text { job change) }\end{array}$} & \multicolumn{3}{|c|}{$\begin{array}{l}\text { Percent of households responding "yes" } \\
\text { to respective questions, } \\
\text { as a percentage of households that ... }\end{array}$} \\
\hline & $\begin{array}{c}\text {...changed } \\
\text { banks most } \\
\text { recently for } \\
\text { some reason } \\
\text { other than a } \\
\text { move }\end{array}$ & $\begin{array}{c}\text {...have } \\
\text { changed } \\
\text { banks } \\
\text { at some time* }\end{array}$ & $\begin{array}{l}\text {...have a } \\
\text { checking or } \\
\text { savings } \\
\text { account* }\end{array}$ \\
\hline $\begin{array}{l}\text { Interest rates, maintenance fees, or } \\
\text { minimum balance requirements }\end{array}$ & 48.8 & 22.0 & 15.3 \\
\hline Location of ATMs or offices & 37.3 & 16.8 & 11.7 \\
\hline Customer service & 56.1 & 25.3 & 17.6 \\
\hline $\begin{array}{l}\text { Access to electronic banking } \\
\text { services }\end{array}$ & 27.0 & 12.2 & 8.5 \\
\hline Previous bank merged with another & 22.6 & 10.2 & 7.1 \\
\hline $\begin{array}{l}\text { Did not respond "yes" to any } \\
\text { specific reason for switching }\end{array}$ & 10.8 & 4.7 & 3.3 \\
\hline Number of observations & 469 & 964 & 1378 \\
\hline
\end{tabular}

* Only those households that had changed banks for some reason other than a relocation were asked the specific reasons for changing banks. These questions are not mutually exclusive. Frequencies are calculated using sampling weights. 
Table 5: Correlations of reasons for most recent bank change, if not for a move or job change

\begin{tabular}{l|c|c|c|c|c}
\hline & Prices & Location & $\begin{array}{c}\text { Customer } \\
\text { Service }\end{array}$ & $\begin{array}{c}\text { Electronic } \\
\text { Services }\end{array}$ & Merger \\
\hline Prices & 1 & 0.031 & 0.067 & 0.124 & -0.074 \\
& & $(0.498)$ & $(0.145)$ & $(0.007)$ & $(0.110)$ \\
Location & 0.031 & 1 & 0.118 & 0.247 & 0.017 \\
& $(0.498)$ & & $(0.010)$ & $(0.0001)$ & $(0.717)$ \\
Customer & 0.067 & 0.118 & 1 & 0.210 & 0.146 \\
Service & $(0.145)$ & $(0.010)$ & & $(0.0001)$ & $(0.002)$ \\
Electronic & 0.124 & 0.247 & 0.210 & 1 & 0.111 \\
Services & $(0.007)$ & $(0.0001)$ & $(0.0001)$ & & $(0.016)$ \\
Merger & -0.074 & 0.017 & 0.146 & 0.111 & 1 \\
& $(0.110)$ & $(0.717)$ & $(0.002)$ & $(0.016)$ & \\
\hline
\end{tabular}

Number of observations: 469

Includes only those households that responded to all the questions above; households were asked these questions if they had changed banks most recently for some reason other than a household move or job change.

P-values for chi-squared test that the correlation coefficient is different from zero are given in parentheses. 
Table 6: Reasons for staying at current main bank

\begin{tabular}{l|c|c}
\hline \multicolumn{1}{c|}{$\begin{array}{c}\text { Reasons for staying } \\
\text { at current main bank }\end{array}$} & $\begin{array}{c}\text { Percent } \\
\text { responding “yes" }\end{array}$ & $\begin{array}{c}\text { Number of } \\
\text { observations }\end{array}$ \\
\hline $\begin{array}{l}\text { Interest rates, maintenance fees, or } \\
\text { minimum balance requirements }\end{array}$ & 59.4 & 1316 \\
\hline Location of ATMs or offices & 73.8 & 1317 \\
\hline Customer service & 75.2 & 1316 \\
\hline $\begin{array}{l}\text { Access to electronic banking } \\
\text { services }\end{array}$ & 58.0 & 1313 \\
\hline $\begin{array}{l}\text { Too much trouble to switch } \\
\text { Did not respond “yes" to any } \\
\text { specific reason for staying }\end{array}$ & 34.4 & 1317 \\
\hline
\end{tabular}

All households that had been at their main bank for at least one year were asked these questions. These questions are not mutually exclusive. Frequencies are calculated using sampling weights. The number of observations for each question excludes nonrespondents. 
Table 7: Correlations of reasons for staying at current main bank

\begin{tabular}{l|c|c|c|c|c}
\hline & Prices & Location & $\begin{array}{c}\text { Customer } \\
\text { Service }\end{array}$ & $\begin{array}{c}\text { Electronic } \\
\text { Services }\end{array}$ & $\begin{array}{c}\text { Too Much } \\
\text { Trouble }\end{array}$ \\
\hline Prices & 1 & $\begin{array}{c}0.107 \\
(0.0001)\end{array}$ & $\begin{array}{c}0.212 \\
(0.0001)\end{array}$ & $\begin{array}{c}0.263 \\
(0.0001)\end{array}$ & $\begin{array}{c}0.182 \\
\text { Location }\end{array}$ \\
& 0.107 & 1 & 0.222 & 0.241 & $0.001)$ \\
Customer & $0.0001)$ & & $(0.0001)$ & $(0.0001)$ & $(0.026)$ \\
Service & $(0.0001)$ & $(0.0001)$ & 1 & 0.231 & -0.231 \\
Electronic & 0.263 & 0.241 & 0.231 & $(0.0001)$ & $(0.0001)$ \\
Services & $(0.0001)$ & $(0.0001)$ & $(0.0001)$ & & -0.035 \\
Too Much & -0.182 & 0.061 & -0.231 & -0.035 & $(0.211)$ \\
Trouble & $(0.0001)$ & $(0.026)$ & $(0.0001)$ & $(0.211)$ & \\
\hline
\end{tabular}

Number of observations: 1312

Includes only those households that responded to all the questions above; households were asked these questions if they had been at their main bank for at least one year.

P-values for chi-squared test that the correlation coefficient is different from zero are given in parentheses. 
Table 8: Frequency distribution: Satisfaction with main bank

\begin{tabular}{l|c|cc}
\hline $\begin{array}{c}\text { Level of satisfaction } \\
\text { with main bank }\end{array}$ & $\begin{array}{c}\text { All households } \\
\text { with accounts } \\
(\%)\end{array}$ & $\begin{array}{c}\text { Households } \\
\text { responding "yes" } \\
\text { to "too much } \\
\text { trouble" to switch } \\
(\%)\end{array}$ & $\begin{array}{c}\text { Households } \\
\text { responding "no" } \\
\text { to "too much } \\
\text { trouble" to switch } \\
(\%)\end{array}$ \\
\hline Very satisfied & 52.6 & 33.3 & 62.7 \\
\hline Moderately satisfied & 34.4 & 43.3 & 30.2 \\
\hline $\begin{array}{l}\text { Neither satisfied nor } \\
\text { dissatisfied }\end{array}$ & 6.5 & 10.0 & 4.5 \\
\hline Moderately dissatisfied & 4.7 & 9.2 & 2.1 \\
\hline Very dissatisfied & 1.8 & 4.1 & 0.4 \\
\hline Number of observations & 1357 & 440 & 851 \\
\hline
\end{tabular}

All 1378 households with a bank account were asked satisfaction levels; 21 households did not respond to the question. Only those households that had been with their main bank for at least one year (1291 households) were asked whether it was "too much trouble" to change banks. These categories are mutually exclusive. Frequencies are calculated using sampling weights. 
Table 9: Response rates to "too much trouble" by satisfaction level

\begin{tabular}{|l|c|c|c|}
\hline & \multirow{2}{*}{$\begin{array}{c}\text { Among all } \\
\text { households* }\end{array}$} & \multicolumn{2}{|c|}{ Satisfaction with main bank } \\
\cline { 3 - 4 } & \multirow{2}{*}{$\begin{array}{c}\text { Very satisfied or } \\
\text { moderately satisfied }\end{array}$} & $\begin{array}{c}\text { Neutral, moderately } \\
\text { dissatisfied or very } \\
\text { dissatisfied }\end{array}$ \\
\hline $\begin{array}{l}\text { Percent that } \\
\text { responded "yes" to } \\
\text { "too much trouble" } \\
\text { to switch }\end{array}$ & 34.4 & 30.2 & 62.9 \\
\hline $\begin{array}{l}\text { Percent that } \\
\text { responded "no" to } \\
\text { "too much trouble" } \\
\text { to switch }\end{array}$ & 65.6 & 69.8 & 37.1 \\
\hline $\begin{array}{l}\text { Number of } \\
\text { observations }\end{array}$ & 1313 & 1135 & 172 \\
\hline
\end{tabular}

*Households were asked reasons for staying at a bank (which included "too much trouble") if they had a bank account and had been with their current depository institution for at least one year. All households with a bank account were asked their satisfaction level with their current bank. The number of observations across satisfaction levels does not sum to the number of observations in the leftmost column because of the nonresponse of 6 households to the question on customer satisfaction. Percentages are calculated using sampling weights. 
Figure 1: Frequency distribution of years at main bank

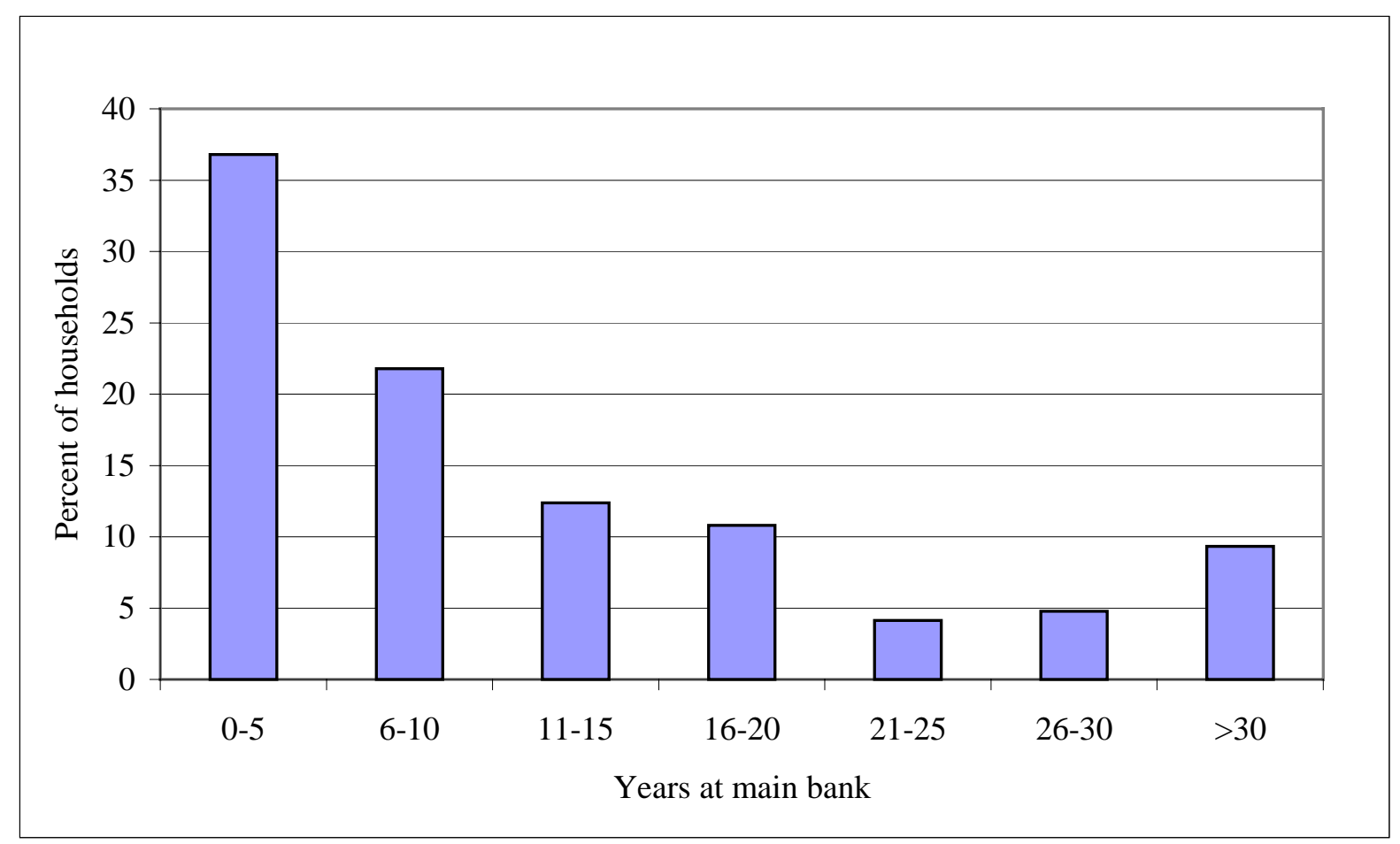

Number of observations: 1333

The distribution shown above displays all values greater than 30 years as a single mass point; the actual distribution in the data set is not top-coded. The maximum tenure recorded in the sample is 63 years. Frequencies are calculated using sampling weights. 
Figure 2: Years at main bank by 'first bank ever'

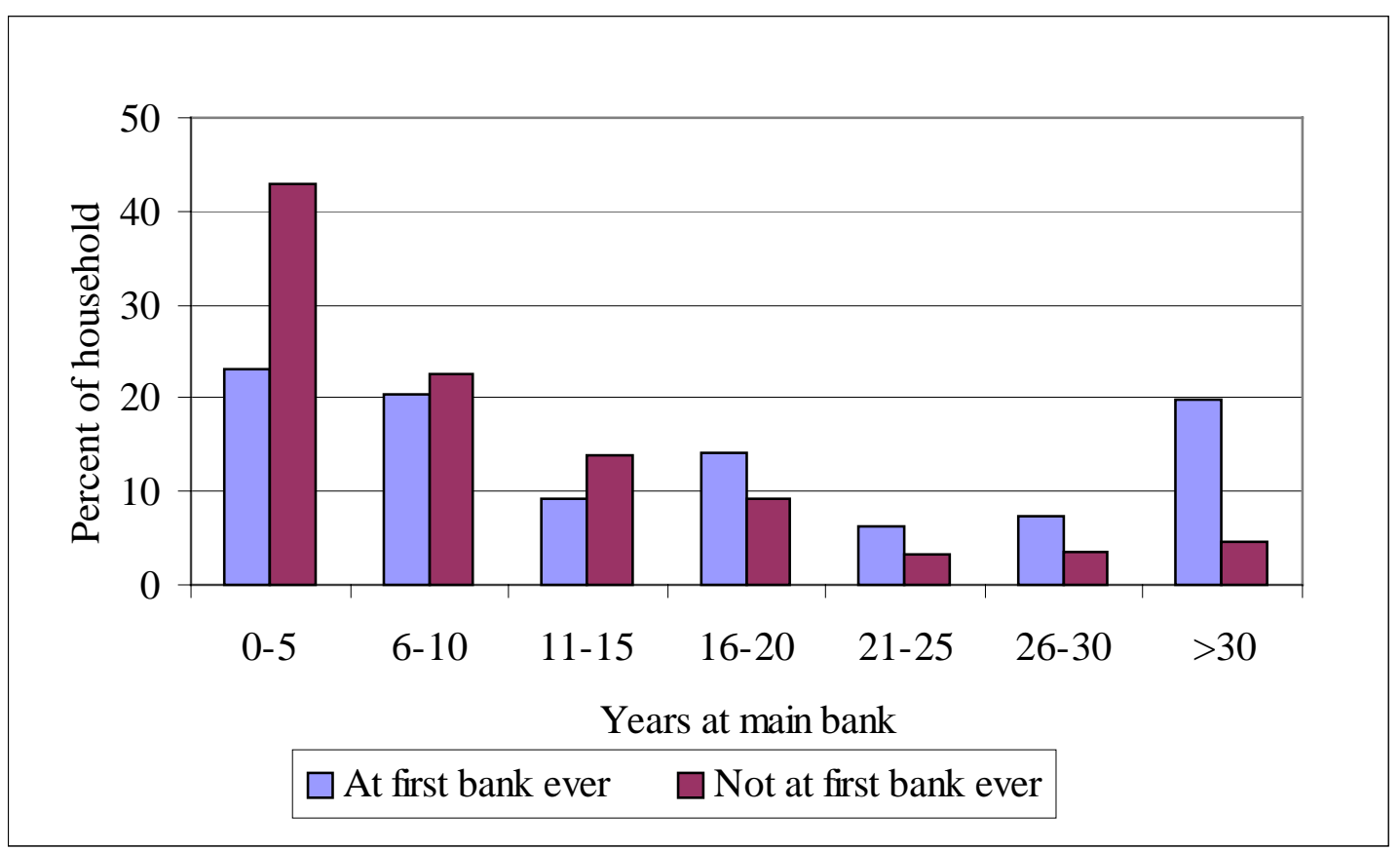

Number of observations: 1328

Frequencies are calculated using sampling weights. 


\section{References}

Amel, D. and T. Hannan (1999), "Establishing Banking Market Definitions through Estimation of Residual Deposit Supply Equations," Journal of Banking and Finance 23(11), 1667-90.

Amel, D. and N. Liang (1997), "Determinants of Entry and Profits in Local Banking Markets," Review of Industrial Organization 12(1), 59-78.

Amel, D. and M. Starr-McCluer (2002), "Market Definition in Banking: Recent Evidence," Antitrust Bulletin 47(1), 63-89.

Berger, A. and G. Udell (1995), "Relationship Lending and Lines of Credit in Small Firm Finance," J. of Business 68(3), 351-381.

Burke, J. (1998), "Divestiture as an Antitrust Remedy in Bank Mergers," Federal Reserve Board Finance and Economics Discussion Series (FEDS) Discussion Paper 199814.

Calem, P. and L. Mester (1995), "Consumer Behavior and the Stickiness of Credit-Card Interest Rates," American Economic Review 85(5), 1327-1336.

Calem, P. and G. Carlino (1991), "The Concentration/Conduct Relationship in Bank Deposit Markets," Review of Economics and Statistics 73, 268-276.

Eaton, B. and R. Lipsey (1996), "Product Differentiation," Handbook of Industrial Organization 1, R. Schmalensee and R. Willig, eds., 725-768.

Hanweck, G. and B. Shull (1999), “The Bank Merger Movement: Efficiency, Stability and Competitive Policy Concerns," The Antitrust Bulletin 44(2), 251-286.

Heitfield, E. (1999), "What Do Interest Rate Data Say About the Geography of Retail Banking Markets?" The Antitrust Bulletin 44(2), 333-347.

Hughes, J. and L. Mester (1998), "Bank Capitalization and Cost: Evidence of Scale Economies in Risk Management and Signaling," Review of Economics and Statistics 80(2), 314-325.

Kennickell, A., M. Starr-McCluer and B. Surette (2000), "Recent Changes in U. S. Family Finances: Results from the 1998 Survey of Consumer Finances," Federal Reserve Bulletin, 86(1), 1-29. 
Kim, M., D. Kliger and B. Vale (2001), "Estimating Switching Costs and Oligopolistic Behavior," working paper, University of Haifa and Norges Bank.

Kiser, E. (2002), "Switching Behavior and Switching Costs in Household Deposits," Review of Industrial Organization 20(4), 349-365.

Klemperer, P. (1995), "Competition when Consumers have Switching Costs: An Overview with Applications to Industrial Organization, Macroeconomics, and International Trade," Review of Economic Studies 62, 515-539.

Kwast, M., M. Starr-McCluer and J. Wolken (1997), "Market Definition and the Analysis of Antitrust in Banking," The Antitrust Bulletin 42(4), 973-995.

Petersen, M. and R. Rajan (1994), "The Benefits of Lending Relationships: Evidence from Small Business Data," Journal of Finance 49(1), 3-37.

Pilloff, S. (1999), "Money Market Mutual Funds: Are They a Close Substitute for Accounts at Insured Depository Institutions?" The Antitrust Bulletin 44(2), 365385.

Prager, R. and T. Hannan (1998), "Do Substantial Horizontal mergers Generate Significant Price Effects? Evidence from the Banking Industry," Journal of Industrial Economics 46(4), 433-452.

Rhoades, S. (1999), "Retail Commercial Banking: An Update on a Period of Extraordinary Change," Review of Industrial Organization 16(4), 357-366.

Sharpe, S. (1997), "The Effect of Consumer Switching Costs on Prices: A Theory and its Application to the Bank Deposit Market," Review of Industrial Organization 12(1), 79-94.

Zephirin, M. (1994), "Switching Costs in the Deposit Market," The Economic Journal 104 (March), 455-561. 